\title{
THE INFLUENCE OF SHORT-TERM HIPOCALORIC NUTRITION ON BODYWEIGHT REDUCTION IN LITHUANIAN OLYMPIC TEAM WRESTLERS
}

\author{
Marius Baranauskas ${ }^{1,3}$, Linas Tubelis ${ }^{2,3}$, Rimantas Stukas ${ }^{1}$, Edmundas Švedas $^{4}$ \\ Laimutė Samsonien $\dot{e}^{5}$, Diana Karanauskiené $\dot{e}^{5}$ \\ Vilnius Universityl, Vilnius, Lithuania, \\ Vilnius Pedagogical University ${ }^{2}$, Lithuania \\ Lithuanian Olympic Sport Center ${ }^{3}$, Vilnius, Lithuania \\ Lithuanian Sports Medicine Center ${ }^{4}$, Vilnius, Lithuania \\ Lithuanian Academy of Physical Education ${ }^{5}$, Kaunas, Lithuania
}

\begin{abstract}
Research background and hypothesis. These days many athletes of combat sports prior contest practice unsafe hipocaloric diets. Hypothetically the content of macronutrient and micronutrient composition of wrestlers' food rations must be corrected individually during the time of bodyweight loss and after weigh control.

Research aim of the present study was to examine the effects of bodyweight reduction on athletes' body weight (BW), lean body mass (LBM), body fat (BF), body fluid (BFL), body protein (BP) and minerals.

Research methods. Wrestlers $(\mathrm{n}=10)$ were measured before, at the end (before weight control) rapid bodyweight reduction and 2 days after contest. Food records were analyzed and macronutrient and micronutrient contributions from meals were assessed. The measures of body mass components were taken using BIA tetra-polar electrodes.

Research results. Analysis of wrestlers 4-day food records revealed average values at $18.2 \pm 10.6 \mathrm{kcal}^{1} \mathrm{~kg}^{-1} \cdot \mathrm{day}^{-1}$, $0.8 \pm 0.4 \mathrm{~g} \cdot \mathrm{kg}^{-1} \cdot \mathrm{day}^{-1}$ of proteins, $2.0 \pm 1.5 \mathrm{~g} \cdot \mathrm{kg}^{-1} \cdot \mathrm{day}^{-1}$ of carbohydrates and $0.8 \pm 0.4 \mathrm{~g} \cdot \mathrm{kg}^{-1} \cdot \mathrm{day}^{-1}$ of fat throughout the period of rapid bodyweight reduction. Low total energy intake contributed to the insufficient on take of vitamins $\mathrm{A}, \mathrm{B}_{1}, \mathrm{~B}_{2}, \mathrm{PP}, \mathrm{D}, \mathrm{E}, \mathrm{B}_{6}$, folic acid and minerals as potassium, calcium, phosphorus, magnesium, iron, zinc intakes during the rapid bodyweight loss season. Additionally wrestlers followed low-carbohydrate and high-fat diet and did not consume adequate energy or carbohydrate diet after the contest.

Discussion and conclusions. During rapid bodyweight loss period athletes showed a significant decrease in BM $(-3.7 \pm 1.9 \mathrm{~kg}, \mathrm{p}<0.05), \operatorname{LBM}(-1.5 \pm 1.3 \mathrm{~kg}, \mathrm{p}<0.05)$, BF $(-2.1 \pm 0.6 \mathrm{~kg}, \mathrm{p}<0.001)$, BFL $(-1.1 \pm 0.9 \mathrm{~kg}$, $\mathrm{p}<0.05)$, minerals $(-0.2 \pm 0.1 \mathrm{~kg}, \mathrm{p}<0.05)$, but not BP $(-0.2 \pm 0.1 \mathrm{~kg}, \mathrm{p} \leq 0.05)$. After contest wrestlers had significant increases in $\mathrm{BM}(+3.1 \pm 1.9 \mathrm{~kg}, \mathrm{p}<0.05)$, BF $(+2.6 \pm 0.5 \mathrm{~kg}, \mathrm{p}<0.001)$ and minerals $(+0.2 \pm 0.1 \mathrm{~kg}, \mathrm{p}<$ $0.05)$, but non-significant increase in LBM $(+1.0 \pm 1.8 \mathrm{~kg}, \mathrm{p}>0.05)$ and BFL $(+0.7 \pm 1.3 \mathrm{~kg}, \mathrm{p}<0.05)$. Wrestlers' food rations must be corrected individually during the time of bodyweight loss, after weigh control and follow-up recovery, during the period of contest.
\end{abstract}

Keywords: nutrition, wrestlers' food rations, weight reduction.

\section{INTRODUCTION}

$\Lambda$ iming at high sports achievements athletes often try to adjust their body mass. Many athletes competing in their weight categories try to reduce their body weight before the competitions at any cost, ignoring the impact of such methods applied on their health and physical working capacity. Thus, analysis of body mass components and continuous supervision of nutrition are prerequisites for high performance in sport. Depending on the duration, body weight loss is divided into short-term (lasting for 24-72 h), moderate (lasting from $72 \mathrm{~h}$ to several weeks), 
and gradual, which lasts from several weeks to several months (Wilmore, 2000). Body weight loss can have a negative impact on athletes' working capacity. However, only a few studies confirm the negative effect of short-term body weight loss on athletes' working capacity (Timpmann et al., 2008; Ööpik, Timpman, 2009). Other studies, on the contrary, did not establish any effect of short-term body weight loss on athletes' working capacity and (or) its decrease during a competition if athletes' dietary habits were appropriate before the competition and their bodies were provided with optimum nutrients and liquids (Felgholm et al., 1993; Rankin, 2006). For this reason much attention should be paid to athletes' diets right after their short-term body weight loss, before, during and after the competition.

Research aim was to study and assess the peculiarities of short-term body weight loss as well as their impact on the indices of body mass components of Lithuanian Olympic team GreekRoman wrestlers.

\section{RESEARCH METHODS}

Aiming at evaluating the impact of short-term body weight loss on the indices of athletes' body mass components we investigated 10 Lithuanian Olympic team Greek-Roman wrestlers aged 15.6 \pm 1.5 years who were reducing their body weight for four days before the competition. The method applied was a survey of actual nutrition which investigated athletes' actual nutrition of three consecutive days, 24 hours a day before athletes' body weight reduction programme; actual nutrition of four consecutive days, 24 hours a day during athletes' body weight reduction programme; and two consecutive days, 24 hours a day during a period of recovery (Figure 1). In accordance with the tables of food chemical composition we calculated the chemical composition and the energy value of athletes' food rations (Sučilienè, 2002). We assessed the nutrient balance in the diets and their conformity with the physiological needs of the body according to the recommended norms of the day (Rekomenduojamos paros maistiniu medžiagu ir energijos normos, 2000). Meeting the energy needs of the body was assessed applying the method of alimentary calorimetry (Position of the American Dietetic Association, 2000; Rekomenduojamos paros maistiniu medžiagu ir energijos normos, 2000; Ainsworth, 2011).

Aiming at establishing and evaluating changes in athletes' total body mass and its separate components during short-term body mass reduction we used BIA tetra-polar electrode method to measure the resistance of the body with 8-12 tangential electrodes at different measuring signal frequencies $(5,50$ and $250 \mathrm{kHz})$, and thus we measured athletes' total body mass, lean body mass, muscle mass, body fat mass, general, intracellular and extracellular body fluids, proteins and minerals in the body. The investigations were carried out before short-term body weight loss, after it and in addition - two days after the competition.

Statistical data processing was carried out using programme package SPSS v.15. The data were analyzed using the following methods of mathematical statistics: we calculated arithmetic means $(\bar{x})$, the data distribution was evaluated according to standard deviation (S). The differences in the indices of athletes' body mass components before and after body mass reduction were evaluated using Student's $t$ test for paired samples. Relations between variables were established using Pearson's correlation coefficient (r).

Figure 1. Research algorithm

\begin{tabular}{|c|c|c|}
\hline \multicolumn{4}{|c|}{ Investigations } \\
\hline $\begin{array}{c}\text { Before short-term body } \\
\text { weight loss }\end{array}$ & $\begin{array}{c}\text { During short-term body weight loss } \\
\text { (before the competition and the } \\
\text { beginning of body weight control) }\end{array}$ & After the competition \\
\hline \multicolumn{3}{|c|}{ The duration of studies: 9 days } \\
\hline Day 1,2,3 & Day 1,2,3,4 & Day 1,2, \\
\hline \begin{tabular}{|c|c|}
\hline $\begin{array}{c}\text { Survey of actual } \\
\text { nutrition }\end{array}$ \\
Measurements of body mass components (total body mass, body fat mass, amount of proteins, \\
minerals and body fluids in the body)
\end{tabular} \\
\hline
\end{tabular}




\section{RESEARCH RESULTS}

We evaluated the impact of most often applied short-term (four-day) body weight loss on the indices of body mass and its components (Table 1) and established that athletes' body mass decreased by $3.7 \pm 1.2 \mathrm{~kg}(\mathrm{p}=0.002)$ on average, and their lean body mass - by $1.5 \pm 1.3 \mathrm{~kg}(\mathrm{p}=0.05)$. Lean body mass decreased due to the decrease of general body fluids - by $1.1 \pm 0.9 \mathrm{~kg}(\mathrm{p}=0.05)$, and intracellular fluids among them - by $0.8 \pm 0.5 \mathrm{~kg}(\mathrm{p}=0.025)$. During body mass reduction the amount of body fat and minerals decreased respectively by $0.2 \pm$ $0.1 \mathrm{~kg}$ and $2.1 \pm 0.6 \mathrm{~kg}(\mathrm{p}=0.003$ and $\mathrm{p}=0.001)$, however, muscle mass and the amount of proteins did not change statistically significantly $(p=0.067$ and $\mathrm{p}=0.136$ ).

Greek-Roman wrestlers' body mass decreased by $5.2 \pm 1.7 \%$ on average because their food rations were extremely hipocaloric. Before the body weight reduction programme the energy values of food rations of Greco-Roman wrestlers, which were $3566 \pm 946 \mathrm{kcal}\left(53.8 \pm 22.1 \mathrm{kcal}^{\circ} \mathrm{kg}^{-1} \cdot \mathrm{day}^{-1}\right)$, covered the energy consumption of the day by $95 \pm 36 \%$; during the short-term body weight loss the energy values of food rations were $1106 \pm 497 \mathrm{kcal}(18.2 \pm$ $\left.10.6 \mathrm{kcal} \cdot \mathrm{kg}^{-1} \cdot \mathrm{day}^{-1}\right)$ on average and they covered only $32 \pm 18 \%$ of the energy consumption of the day (Table 2). The amounts of nutrients in hiopocaloric diets equaled to $2.0 \pm 1.5 \mathrm{~g} \cdot \mathrm{kg}^{-1} \cdot \mathrm{day}^{-1}, 0.8 \pm 0.4 \mathrm{~g} \cdot \mathrm{kg}^{-}$ ${ }^{1} \cdot$ day $^{-1}$ and $0.8 \pm 0.4 \mathrm{~g} \cdot \mathrm{kg}^{-1} \mathrm{day}^{-1}$ respectively and were unbalance (Table 3). Misbalance was due to the energy values of carbohydrates, proteins and fats which did not conform to the requirements of balanced diets in the food rations of Greco-Roman wrestlers: $43.2 \pm 6.9 \%, 18.3 \pm 2.2 \%$ and $38.5 \pm$ $5.4 \%$ (Table 4). Body fat reduction can be explained by both the decreased energy value $(r=0.4$; $\mathrm{p}=0.04$ ), and the decreasedamounts of carbohydrates $(r=0.4 ; p=0.04)$, proteins $(r=0.5 ; p=0.03)$ and fats $(r=0.3 ; p=0.05)$ of Greco-Roman wrestlers food rations during short-term hipocaloric nutrition.

Table 1. Athletes' body mass components $(\bar{x} \pm \mathbf{S})$

\begin{tabular}{|c|c|c|c|c|c|}
\hline \multirow[b]{3}{*}{ Body mass components } & \multicolumn{3}{|c|}{ Groups } & \multirow{2}{*}{\multicolumn{2}{|c|}{ Statistical indices }} \\
\hline & 1 & 2 & 3 & & \\
\hline & $\begin{array}{c}\text { Before } \\
\text { body mass } \\
\text { reduction }\end{array}$ & $\begin{array}{c}\text { After } \\
\text { body mass } \\
\text { reduction } \\
\text { before the } \\
\text { competition } \\
\end{array}$ & $\begin{array}{c}2 \text { days after } \\
\text { body mass } \\
\text { reduction } \\
\text { (after } \\
\text { competition) }\end{array}$ & $\begin{array}{l}\text { Difference between } \\
\text { Group } 1 \text { and } 2\end{array}$ & $\begin{array}{l}\text { Difference between } \\
\text { Group } 2 \text { and } 3\end{array}$ \\
\hline Body mass & $70.6 \pm 16.9$ & $67 \pm 15.7$ & $70.1 \pm 16.3$ & $\mathrm{t}=6.805, \mathrm{df}=9, \mathrm{p}=0.002$ & $\mathrm{t}=-3.565, \mathrm{df}=9, \mathrm{p}=0.023$ \\
\hline Lean body mass, $\mathrm{kg}$ & $58.4 \pm 11$ & $56.9 \pm 10.1$ & $57.9 \pm 11.4$ & $\mathrm{t}=2.746, \mathrm{df}=9, \mathrm{p}=0.050$ & $\mathrm{t}=-1.290, \mathrm{df}=9, \mathrm{p}=0.267$ \\
\hline Lean body mass, $\%$ & $83.4 \pm 4.7$ & $85.9 \pm 5.9$ & $82.6 \pm 4$ & $\mathrm{t}=-4.250, \mathrm{df}=9, \mathrm{p}=0.013$ & $\mathrm{t}=3.632, \mathrm{df}=9, \mathrm{p}=0.022$ \\
\hline Muscle mass, $\mathrm{kg}$ & $54.3 \pm 10$ & $52.9 \pm 9.2$ & $53.7 \pm 10.4$ & $\mathrm{t}=2.494, \mathrm{df}=9, \mathrm{p}=0.067$ & $\mathrm{t}=-1.053, \mathrm{df}=9, \mathrm{p}=0.352$ \\
\hline Muscle mass, $\%$ & $77.7 \pm 4.8$ & $80 \pm 5.8$ & $76.8 \pm 4$ & $\mathrm{t}=-4.247, \mathrm{df}=9, \mathrm{p}=0.013$ & $\mathrm{t}=3.682, \mathrm{df}=9, \mathrm{p}=0.021$ \\
\hline $\begin{array}{l}\text { Muscle and fat mass } \\
\text { index }\end{array}$ & $5.2 \pm 1.9$ & $6 \pm 3.9$ & $4.7 \pm 1.4$ & $\mathrm{t}=-0.632, \mathrm{df}=9, \mathrm{p}=0.562$ & $\mathrm{t}=0.865, \mathrm{df}=9, \mathrm{p}=0.436$ \\
\hline $\mathrm{BMI}, \mathrm{kg} \cdot \mathrm{m}^{2}$ & $23.3 \pm 2.6$ & $22.1 \pm 2.4$ & $23.1 \pm 2.5$ & $\mathrm{t}=10.95, \mathrm{df}=9, \mathrm{p}<0.001$ & $\mathrm{t}=-3.715, \mathrm{df}=9, \mathrm{p}=0.021$ \\
\hline General body fluid, $\mathrm{kg}$ & $42 \pm 7.9$ & $40.9 \pm 7.3$ & $41.7 \pm 8.2$ & $\mathrm{t}=2.692, \mathrm{df}=9, \mathrm{p}=0.050$ & $\mathrm{t}=-1.258, \mathrm{df}=9, \mathrm{p}=0.277$ \\
\hline General body fluid, \% & $60.1 \pm 3.5$ & $61.8 \pm 4.2$ & $59.5 \pm 2.9$ & $\mathrm{t}=-4.229, \mathrm{df}=9, \mathrm{p}=0.013$ & $\mathrm{t}=3.665, \mathrm{df}=9, \mathrm{p}=0.021$ \\
\hline Intracellular fluid, $\mathrm{kg}$ & $27.5 \pm 5.2$ & $26.7 \pm 4.8$ & $27.3 \pm 5.5$ & $\mathrm{t}=3.516, \mathrm{df}=9, \mathrm{p}=0.025$ & $t=-1.724, d f=9, p=0.160$ \\
\hline Extracellular fluid, kg & $14.5 \pm 2.7$ & $14.3 \pm 2.5$ & $14.4 \pm 2.7$ & $\mathrm{t}=1.580, \mathrm{df}=9, \mathrm{p}=0.189$ & $\mathrm{t}=-0.434, \mathrm{df}=9, \mathrm{p}=0.686$ \\
\hline Proteins, kg & $12.2 \pm 2.1$ & $12 \pm 1.9$ & $12.1 \pm 2.3$ & $\mathrm{t}=1.863, \mathrm{df}=9, \mathrm{p}=0.136$ & $\mathrm{t}=-0.425, \mathrm{df}=9, \mathrm{p}=0.693$ \\
\hline Proteins, $\%$ & $17.6 \pm 1.3$ & $18.2 \pm 1.6$ & $17.3 \pm 1.1$ & $\mathrm{t}=-4.238, \mathrm{df}=9, \mathrm{p}=0.013$ & $\mathrm{t}=3.698, \mathrm{df}=9, \mathrm{p}=0.021$ \\
\hline Mineral substances, $\mathrm{kg}$ & $4.1 \pm 0.9$ & $3.9 \pm 0.9$ & $4.1 \pm 0.9$ & $\mathrm{t}=6.325 . \mathrm{df}=9, \mathrm{p}=0.003$ & $\mathrm{t}=-5.880 . \mathrm{df}=9, \mathrm{p}=0.004$ \\
\hline Mineral substances, \% & $5.8 \pm 0.1$ & $5.9 \pm 0.1$ & $5.9 \pm 0.1$ & $\mathrm{t}=-0.535 . \mathrm{df}=9, \mathrm{p}=0.621$ & $\mathrm{t}=-0.535 . \mathrm{df}=9, \mathrm{p}=0.621$ \\
\hline Body fat, $\mathrm{kg}$ & $12.2 \pm 6.2$ & $10.1 \pm 6$ & $12.7 \pm 5.5$ & $\mathrm{t}=7.835 . \mathrm{df}=9, \mathrm{p}=0.001$ & $\mathrm{t}=-11.131 . \mathrm{df}=9, \mathrm{p}<0.001$ \\
\hline Body fat, \% & $16.5 \pm 4.9$ & $14.1 \pm 5.9$ & $17.4 \pm 3.9$ & $\mathrm{t}=4.393 . \mathrm{df}=9, \mathrm{p}=0.012$ & $\mathrm{t}=-3.608 . \mathrm{df}=9, \mathrm{p}=0.023$ \\
\hline
\end{tabular}


The food rations of athletes who were reducing their body weight contained lower amounts of minerals - potassium, calcium, magnesium, phosphorus, iron and zinc - compared to the recommended daily norms. The amount of potassium made up $64 \pm 19 \%$, calcium $-52 \pm$ $25 \%$, magnesium $-35 \pm 13 \%$, phosphorus $-55 \pm$ $20 \%$, iron $-57 \pm 21 \%$ and zinc $-45 \pm 12 \%$ of the recommended daily intake (Table 5). Only the amounts of sodium and vitamins $\mathrm{C}$ and $\mathrm{B}_{1}$ were sufficient. They amounted to $135 \pm 13$ and $124 \pm$ $52 \%$ respectively of the recommended norm (Table 6). Low energy intake contributed to insufficient amounts of vitamin $\mathrm{D}$, almost all $\mathrm{B}$ group vitamins $\mathrm{B}_{1}, \mathrm{~B}_{2}, \mathrm{PP}, \mathrm{B}_{6}$, folic acid and antioxidants vitamins $A$ and $E$. The amount of vitamin $D$ was $17 \pm 6, B_{1}-$ $26 \pm 15, \mathrm{~B}_{2}-45 \pm 18, \mathrm{~B}_{6}-65 \pm 21, \mathrm{E}-70 \pm 35$, folic acid $-44 \pm 18 \%$ of the recommended daily intake.
After short-term body weight reduction, the recovery of the body and its rate are of great importance. Our research findings showed that in the period of two days after the contest the recovery processes of total body mass, minerals and body fat for Greco-Roman wrestlers were optimal (Table 1). After the competition the total body weight of the research participants statistically significantly increased from $67 \pm 15.7 \mathrm{~kg}$ to $70.1 \pm 16.3 \mathrm{~kg}$ $(\mathrm{p}=0.023)$, body fat - from $10.1 \pm 6.0 \mathrm{~kg}$ to $12.7 \pm$ $5.5 \mathrm{~kg}(\mathrm{p}<0.001)$. However, due to insufficient recovery of fluid in the body the recovery processes of lean body mass were too slow. Athletes' lean body mass increased from $56.9 \pm 10.1 \mathrm{~kg}$ to $57.9 \pm$ $11.4 \mathrm{~kg}$, the amount of general body fluid - from $40.9 \pm 7.3 \mathrm{~kg}$ to $41.7 \pm 8.2 \mathrm{~kg}$, including intracellular fluid - from $26.7 \pm 4.8 \mathrm{~kg}$ to $27.3 \pm 5.5 \mathrm{~kg}$, after the competition, but the increases were not statistically significant $(\mathrm{p}=0.267 ; \mathrm{p}=0.277 ; \mathrm{p}=0.160)$.
Table 2. Athletes' energy expenditure and the energy value of their food rations $(\bar{x} \pm S)$

Note. RDN - recommended daily norm.

\begin{tabular}{|l|c|c|c|}
\hline \multicolumn{1}{|c|}{ Energy value } & $\begin{array}{c}\text { Before body mass } \\
\text { reduction }\end{array}$ & $\begin{array}{c}\text { During body } \\
\text { mass reduction }\end{array}$ & $\begin{array}{c}\text { After body mass } \\
\text { reduction }\end{array}$ \\
\hline \multicolumn{4}{|c|}{ Daily energy expenditure } \\
\hline Energy expenditure $\left(\mathrm{kcal} \cdot \mathrm{day}^{-1}\right)$ & $3911 \pm 792$ & $3751 \pm 741$ & $2676 \pm 416$ \\
\hline Energy expenditure $\left(\mathrm{kcal}^{\mathrm{k}} \mathrm{kg}^{-1} \cdot \mathrm{day}^{-1}\right)$ & $55.8 \pm 2.3$ & $56.4 \pm 2.4$ & $38.8 \pm 3.4$ \\
\hline \multicolumn{4}{|c|}{ Energy value of food rations } \\
\hline Energy value $\left(\mathrm{kcal} \cdot \mathrm{day}^{-1}\right)$ & $3566 \pm 946$ & $1106 \pm 497$ & $2188 \pm 403$ \\
\hline Energy value $\left(\mathrm{kcal} \cdot \mathrm{kg}^{-1} \cdot \mathrm{day}^{-1}\right)$ & $53.8 \pm 22.1$ & $18.2 \pm 10.6$ & $33.3 \pm 13.4$ \\
\hline \multicolumn{2}{|c|}{ Ratio of energy consumption and expenditure (percent) } \\
\hline RDN, \% & $95 \pm 36$ & $32 \pm 18$ & $84 \pm 26$ \\
\hline
\end{tabular}

Table 3. Composition of athletes' food rations carbohydrates, proteins, fats $(\bar{x} \pm \mathbf{S})$

\begin{tabular}{|c|c|c|c|c|c|}
\hline Nutrients & $\begin{array}{c}\text { Before } \\
\text { body mass } \\
\text { reduction }\end{array}$ & $\begin{array}{c}\text { During } \\
\text { body mass } \\
\text { reduction }\end{array}$ & 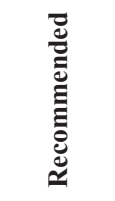 & $\begin{array}{l}\text { After body mass } \\
\text { reduction }\end{array}$ & 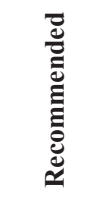 \\
\hline Proteins $\left(\mathrm{g} \cdot \mathrm{kg}^{-1} \cdot \mathrm{day}^{-1}\right)$ & $1.95 \pm 0.8$ & $0.8 \pm 0.4$ & $1.4-2$ & $1.2 \pm 0.4$ & $1-1.5$ \\
\hline Carbohydrates $\left(\mathrm{g} \cdot \mathrm{kg}^{-1} \cdot \mathrm{day}^{-1}\right)$ & $6.9 \pm 2.9$ & $2.0 \pm 1.5$ & $7-9$ & $3.9 \pm 1.7$ & $5-6$ \\
\hline Fats $\left(\mathrm{g} \cdot \mathrm{kg}^{-1} \cdot \mathrm{day}^{-1}\right)$ & $2 \pm 0.8$ & $0.8 \pm 0.4$ & $1.2-1.8$ & $1.5 \pm 0.5$ & $0.8-1.3$ \\
\hline
\end{tabular}

Table 4. Percentage of energy value of the main nutrients received from athletes' food rations $(\bar{x} \pm \mathbf{S})$

\begin{tabular}{|c|c|c|c|c|}
\hline $\begin{array}{l}\text { Supply of energy } \\
\text { value (percent) }\end{array}$ & $\begin{array}{l}\text { Before body mass } \\
\text { reduction }\end{array}$ & $\begin{array}{l}\text { During body mass } \\
\text { reduction }\end{array}$ & $\begin{array}{l}\text { After body mass } \\
\text { reduction }\end{array}$ & 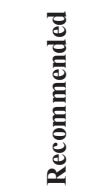 \\
\hline Carbohydrates & $50.9 \pm 4.8$ & $43.2 \pm 6.9$ & $46.6 \pm 3.4$ & $55-65$ \\
\hline Proteins & $14.7 \pm 1.6$ & $18.3 \pm 2.2$ & $14.8 \pm 2.4$ & $10-15$ \\
\hline Fats & $34.7 \pm 4$ & $38.5 \pm 5.4$ & $39.9 \pm 2.3$ & $20-30$ \\
\hline
\end{tabular}




\begin{tabular}{|l|c|c|c|c|c|c|}
\hline \multirow{2}{*}{$\begin{array}{c}\text { Mineral } \\
\text { substances }\end{array}$} & \multicolumn{2}{|c|}{ Before body mass reduction } & \multicolumn{2}{c|}{$\begin{array}{c}\text { During body mass } \\
\text { reduction }\end{array}$} & \multicolumn{2}{c|}{ After body mass reduction } \\
\cline { 2 - 7 } & mg·day $^{-1}$ & RDI \% & mg·day $^{-1}$ & RDI \% & mg·day $^{-1}$ & RDI \% \\
\hline Sodium & $5556 \pm 1275$ & $370 \pm 85$ & $1570 \pm 854$ & $105 \pm 57$ & $3316 \pm 390$ & $221 \pm 26$ \\
\hline Potassium & $4335 \pm 761.4$ & $173 \pm 30$ & $1600 \pm 473$ & $64 \pm 19$ & $2892 \pm 721$ & $116 \pm 29$ \\
\hline Calcium & $1626 \pm 438$ & $203 \pm 55$ & $418 \pm 203$ & $52 \pm 25$ & $968 \pm 224$ & $121 \pm 28$ \\
\hline Magnesium & $546 \pm 143.6$ & $136 \pm 36$ & $141.4 \pm 52.5$ & $35 \pm 13$ & $275 \pm 78$ & $69 \pm 20$ \\
\hline Phosphorus & $2185 \pm 593$ & $182 \pm 49$ & $659 \pm 239$ & $55 \pm 20$ & $1204 \pm 214$ & $100 \pm 18$ \\
\hline Iron & $25.2 \pm 5.5$ & $210 \pm 46$ & $6.9 \pm 2.5$ & $57 \pm 21$ & $15.9 \pm 2.1$ & $132 \pm 17$ \\
\hline Zinc & $18.2 \pm 4.5$ & $121 \pm 30$ & $6.8 \pm 1.8$ & $45 \pm 12$ & $10.3 \pm 0.9$ & $69 \pm 6$ \\
\hline
\end{tabular}

Table 5. Mineral substances in athletes' mean food rations $(\bar{x} \pm S)$

Note. RDI - recommended daily intake.

\begin{tabular}{|c|c|c|c|c|c|c|}
\hline \multirow[t]{2}{*}{ Vitamins } & \multicolumn{2}{|c|}{ Before body mass reduction } & \multicolumn{2}{|c|}{$\begin{array}{l}\text { During body mass } \\
\text { reduction }\end{array}$} & \multicolumn{2}{|c|}{$\begin{array}{l}2 \text { days after body } \\
\text { mass reduction (after } \\
\text { competition) }\end{array}$} \\
\hline & $\begin{array}{c}\left(\mathrm{mg}^{*} \cdot \mu \mathrm{g}^{* *}\right. \\
\left.\mathrm{day}^{-1}\right)\end{array}$ & RDI \% & $\begin{array}{c}\left(\mathrm{mg}^{*} \cdot \mu \mathrm{g}^{* *}\right. \\
\left.\mathrm{day}^{-1}\right)\end{array}$ & RDI \% & & RDI \% \\
\hline $\mathrm{B}_{1}$ & $1.7 \pm 0.2 *$ & $121 \pm 14$ & $0.4 \pm 0.2 *$ & $26 \pm 15$ & $1.4 \pm 0.4$ & $103 \pm 28$ \\
\hline $\mathrm{B}_{2}$ & $3 \pm 0.8^{*}$ & $178 \pm 48$ & $0.8 \pm 0.3^{*}$ & $45 \pm 18$ & $2.1 \pm 0.4$ & $123 \pm 22$ \\
\hline PP & $26.9 \pm 7^{*}$ & $150 \pm 39$ & $10.8 \pm 2.7^{*}$ & $60 \pm 15$ & $15 \pm 2.8$ & $83 \pm 16$ \\
\hline $\mathrm{B}_{6}$ & $3.1 \pm 0.5^{*}$ & $154 \pm 27$ & $1.3 \pm 0.4^{*}$ & $65 \pm 21$ & $2 \pm 0.4$ & $100 \pm 20$ \\
\hline $\mathrm{B}_{12}$ & $7.1 \pm 1.6^{* *}$ & $236 \pm 54$ & $3.7 \pm 1.6 * *$ & $124 \pm 52$ & $5.2 \pm 0.7$ & $175 \pm 25$ \\
\hline Folic acid & $262 \pm 48 * *$ & $131 \pm 24$ & $87.8 \pm 35.3^{* *}$ & $44 \pm 18$ & $172 \pm 28$ & $86 \pm 14$ \\
\hline $\mathrm{D}$ & $4.3 \pm 1.7^{* *}$ & $85 \pm 34$ & $0.8 \pm 0.4 * *$ & $17 \pm 6$ & $1.1 \pm 0.3$ & $23 \pm 6$ \\
\hline \multicolumn{7}{|c|}{ Antioxidants } \\
\hline A & $1393 \pm 400 * *$ & $140 \pm 40$ & $382 \pm 200 * *$ & $38 \pm 20$ & $587 \pm 183$ & $60 \pm 18$ \\
\hline $\mathrm{E}$ & $22.1 \pm 5^{*}$ & $221 \pm 50$ & $6.9 \pm 3.5^{*}$ & $70 \pm 35$ & $10.6 \pm 2.4$ & $106 \pm 25$ \\
\hline $\mathrm{C}$ & $72.5 \pm 16.5^{*}$ & $121 \pm 27$ & $81 \pm 26^{*}$ & $135 \pm 13$ & $179 \pm 159$ & $297 \pm 264$ \\
\hline
\end{tabular}

In the period of two days after the competition the energy value of the food rations for GrecoRoman wrestlers was $33 \pm 13.4 \mathrm{kcal} \cdot \mathrm{kg}^{-1} \cdot \mathrm{day}^{-1}$ on average, and it was lower than the recommended norm of the day $-38 \pm 14.2 \mathrm{kcal} \cdot \mathrm{kg}^{-1} \cdot \mathrm{day}^{-1}$, thus it amounted to $84 \pm 26 \%$ of the recommended norm of the day (Table 2). The amount of proteins was $1.2 \pm 0.4 \mathrm{~g} \cdot \mathrm{kg}^{-1} \cdot \mathrm{day}^{-1}$ and thus it matched the recommended norm of proteins $-1-1.5 \mathrm{~g} \cdot \mathrm{kg}^{-1} \cdot \mathrm{day}^{-1}$. The amount of fat was sufficient $-1.5 \pm 0.5 \mathrm{~g} \cdot \mathrm{kg}^{-}$ ${ }^{1}$ day ${ }^{-1}$, and the amount of carbohydrates, which was $3.9 \pm 1.7 \mathrm{~g} \cdot \mathrm{kg}^{-1} \cdot \mathrm{day}^{-1}$ on average, did not reach the recommended daily intake of $5-6 \mathrm{~g} \cdot \mathrm{kg}^{-1} \cdot \mathrm{day}^{-1}$ (Table 3). The amounts of vitamins A, D, PP, folic acid, calcium and zinc did not reach the recommended norms of the day either (Tables 5 and 6).
Note. RDI - recommended daily intake.

Table 6. Vitamins in athletes' mean food rations $(\bar{x} \pm S)$

\section{DISCUSSION}

So far there has not been any research in Lithuania about dietary peculiarities of elite wrestlers who were trying to reduce their body weight before the competition. Our research findings revealed that in a very short period of time Greco-Roman wrestlers reduced their body mass at the expense of body fat and fluid by $5.2 \%$. Similar body mass loss of 4-6\% was found for Estonian wrestlers, who reduced the energy value of their food rations before the competition to $861 \mathrm{kcal}-$ $1525 \mathrm{kcal}$ (Timpmann et al., 2008). In contrast, the evaluation of 12 Japanese wrestlers and the impact of 7-day body weight reduction on their body mass indices showed that in the short-term period of 
body weight reduction their body mass decreased more, i. e. by $7.3 \%$, body fat - by $9.3 \%$, lean body mass and general body fluid - by $5.9 \%$ (Kukidome et al., 2008).

According to the findings of researchers involved in the studies o athletes' nutrition, when wrestlers reduce their body weight rapidly, the decrease in their body fat is affected not so much by the low energy values of their food, but low amounts of carbohydrates in their food (Shwartz et al., 1995; Johnson et al., 2009), when the processes of ketogenesis become more intensive in athletes' bodies and glucose oxidation in muscles becomes slower (Peters et al., 2001), metabolism of triacilglycerols in the body fat, free fatty acids in blood plasma and the whole body fat become more intense, thus due to greater energy expenditure both body fat mass and muscle mass are reduced in athletes' bodies. Our research results showed different results - the decrease in body fat mass for Greek-Roman wrestlers during a period of 4 days was affected by low energy values of food, as well as low amounts of proteins, fats and carbohydrates in their food rations.

However, scientists emphasize that lowcalorie diet of athletes in combat sports, where the energy value $\%$ of carbohydrates is from 12 to 50 , and when dehydration of the body is increased (inadequate amount of fluids in food, saunas and baths, etc.), the supplies of muscle and liver glycogen is reduced by $54 \%$, and this negatively affects the indices of aerobic working capacity (Ööpik, Timpmann, 2009; Timpmann et al., 2008). Our research findings confirmed that short-term low-calorie nutrition of Greek-Roman wrestlers, where the energy value\% of carbohydrates is only 43 , was irrational, unbalanced and could negatively affect the indices of aerobic working capacity of wrestlers during the competition.

Besides, researchers have established that shortterm low-calorie nutrition, when the energy values of food rations make $18 \mathrm{kcal} \cdot \mathrm{kg}^{-1} \cdot \mathrm{day}^{-1}$, and the amount of proteins $-0.8 \mathrm{~g} \cdot \mathrm{kg}^{-1} \cdot \mathrm{day}^{-1}$, affects more intensive processes of protein degradation in athletes' bodies as well as negative balance of nitrogen. For this reason athletes who are trying to reduce their body weight are recommended to consume more proteins in their food rations $-1.2-1.6 \mathrm{~g} \cdot \mathrm{kg}^{-1} \cdot \mathrm{day}^{-1}$ (Wilmore, 2000). Other authors suggest that negative balance of nitrogen and impaired immune system are caused by low energy values of food rations despite the amounts of proteins consumed (Umeda et al., 2004; Tsai et al., 2009). We should note that ours research results do not coincide with the results obtained by other authors. In our case, when the energy values of athletes' 4-day food rations were $18.3 \mathrm{kcal} \cdot \mathrm{kg}^{-}$ ${ }^{1} \cdot \mathrm{day}^{-1}$ and the amount of proteins $-0.8 \mathrm{~g} \cdot \mathrm{kg}^{-1} \cdot \mathrm{day}^{-1}$, neither the muscle mass nor the amount of proteins in the body decreased statistically significantly. We suppose that a 4-day period of low-calorie and lowprotein diet is too short to have a negative effect on the muscle mass and the amount of proteins in wrestlers' bodies.

On the other hand, when reducing body weight, it is very important to ensure the necessary balance of fluids in athletes' bodies. When dehydration is applied during short-term body weight reduction, rehydration processes require from 24 to 48 hours (Rankin et al., 2006) and athletes are recommended to consume the amount of water or other drinks for 1.5 times bigger than the recommended one (Rankin, 1996; Rankin et al., 2006). Bigger than $2 \%$ dehydration of the body is not recommended for athletes because the blood gets thicker, the body temperature rises and working capacity decreases. In our study the dehydration of athletes' bodies before the competition was only $1.6 \%$. On the other hand, our research findings confirmed that after the competition the amount of fluid in Greek-Roman wrestlers' bodies amounted to $80 \%$ of the fluid before the body weight reduction program, and this can be explained by little amounts of drinks during the competition and after it as well as rather slow processes of rehydration in athletes' bodies.

To sum up, during the short-term body weight reduction program for athletes in combat sports, the energy values of their food rations, the amounts of proteins, carbohydrates, vitamins $\mathrm{A}, \mathrm{B}_{1}, \mathrm{~B}_{2}, \mathrm{PP}$, $\mathrm{D}, \mathrm{E}, \mathrm{B}_{6}$, folic acid and such minerals as potassium, calcium, phosphorus, magnesium, iron and zinc are too low, so the food rations and the amounts of biologically active substances for athletes during the short-term body weight reduction program should be modified individually. In the period of two days after the short-term body weight reduction, the recovery processes of the lean body mass and general body fluid are too slow, and the amounts of water, energy value, carbohydrates, vitamins A, D, PP, folic acid and minerals like calcium and zinc are inadequate. 


\section{CONCLUSIONS AND PERSPECTIVES}

1. Short-term low-calorie nutrition, the energy value of which is $20 \mathrm{kcal} \cdot \mathrm{kg}^{-1} \cdot \mathrm{day}^{-1}$ and the energy values of carbohydrates, proteins, and fats in food rations make up respectively $43 / 18 / 39 \%$, when the dehydration of the body is $1.6 \%$, is effective for overall body weight reduction $(p=0.05)$, lean body mass reduction $(\mathrm{p}=0.05)$, and body fat mass reduction $(p<0.001)$ for athletes in combat sports.
2. The energy values of athletes' 4-day food rations lower than $20 \mathrm{kcal} \cdot \mathrm{kg}^{-1} \cdot \mathrm{day}^{-1}$ and the amount of proteins $-0.8 \mathrm{~g}^{\mathrm{kg}} \mathrm{kg}^{-1} \cdot \mathrm{day}^{-1}$ were not enough to have a significant impact on the muscle mass $(p>0.05)$ or the amount of proteins $(p>0.05)$ in the body.

3. During the recovery period the energy values and amounts of carbohydrates and fluid in wrestlers' food rations are inadequate as they influence slow processes of lean body mass recovery $(\mathrm{p}>0.05)$ and general body fluid recovery $(\mathrm{p}>0.05)$.

\section{REFERENCES}

Ainsworth, B. E., Haskell, W. L., Herrmann, S. D. et al. (2011). Compendium of physical activities: Aa second update of codes and MET values. Medicine and Science in Sports and Exercise, 43 (8), 1581.

Felgholm, M., Koskinen, R., Laasko, J., Rankinen, T., Roukonen, I. (1993). Gradual and rapid weight loss: Effects on nutrition and performance in male athletes. Medicine and Science in Sports and Exercise, 25 (3), 371-377.

Johnson, N. A., Stannard, S. R., Rownalds, D. S. et al. (2009). Effect of short-term starvation versus high-fat die ton intramyocellular triglyceride accumulation and insulin resistance in physically fit men. Experimental Physiology, 91 (4), 693-703.

Kukidome, T., Shirai, K., Kubo, J. et al. (2008). MRI evaluation of body composition changes in wrestlers undergoing rapid weight loss. British Journal of Sports Medicine, 42 (10), 814-818.

Ööpik, V., Timpmann, S. (2009). Weigh loss and physical performance capacity in combat athletes: Impact of nutritional factors. Sporto mokslas, 1 (55), 33-39.

Peters, S. J., Harris, R. A., Wu, P., Pehleman, T. L., Heigenhauser, G. J., Spriet, L. L. (2001). Human skeletal muscle PDH kinase activity and izoform expression during a 3 - day high-fat/low-carbohydrate diet. American Journal of Physiology, 281, 1151-1158.

Position of the American Dietetic Association. Dietitians of Canada, and the American College of Sports Medicine: Nutrition and athletic performance. (2000). Journal of the American Dietetic Association, 100, 1543-1556.

Rankin, J. W. (2006). Making weight in sports. In L. Burke, V. Deakin (Eds.), Clinical Sports Nutrition. Australia: McGrraw-Hill. P. 175-188.

Rankin, J. W., Ocel, J. V., Craft, L. L. (1996). Effect of weight loss and refeeding diet composition on anaerobic performance in wrestlers. Medicine and Science in Sports and Exercise, 28, 1292-1299.

Rankin, J. W., Shute, M., Heffron, S. P., Saker, K. E. (2006). Energy restriction but not protein source effects antooxidants capacity in athletes. Free Radical Biology and Medicine, 41 (6), 1001-1009.

Rekomenduojamos paros maistiniu medžiagu ir energijos normos. (2000). Vilnius.

Schwarz, J. M., Neese, R. A., Turner, S., Dare, D., Hellerstein, M. K. (1995). Short-term alterations in carbohydrate energy intake in humans. Striking effects on hepatic glucose production de novo lipogenesis lipolysis, and whole-body fuel selection. Journal of Clinical Investigation, 96, 2735-2743.

Sučilienè, S., Abaravičius, A. (2002). Maisto produktu sudètis. Vilnius. P. 10-315.

Timpmann, S., Ööpik, V., Pääsuke, M., Medijainen, L., Ereline, J. (2008). Acute effects of self-selected regimen of rapid body mass loss in combat sports athletes. Journal of Sports Science and Medicine, 7, 210-217.

Tsai, M. L., Chan, K. M., Chang, C. K., Fang, S. H. (2009). Changes of mucosal immunity and antioxidation activity in elite male Taiwanese taekwondo athletes associated with intensive training and rapid weight loss. British Journal of Sports Medicine. 43 (11), 845-850.

Umeda, T., Nakaji, S., Shimoyama, T. et al. (2004). Adverse effects of energy restriction on changes in immunoglobulins and complements during weight reduction in judoists. Journal of Sports Medicine and Physical Fitness, 44 (3), 328-394.

Wilmore, J. H. (2000). Weight category sports. In R. J. Maughan (Ed.), Nutrition in Sport. Oxford, UK: Blackwell Science Ltd. P. 637-645. 


\title{
LIETUVOS OLIMPINĖS PAMAINOS IMTYNININKŲ MITYBOS YPATUMAI TRUMPALAIKIO KŪNO MASĖS MAŽINIMO METU
}

\author{
Marius Baranauskas ${ }^{1,3}$, Linas Tubelis ${ }^{2,3}$, Rimantas Stukas $^{1}$, Edmundas Švedas $^{4}$, \\ Laimutė Samsonien $\dot{e}^{5}$, Diana Karanauskiené $\dot{\mathbf{s}}^{5}$ \\ Vilniaus universitetas ${ }^{1}$, Vilnius, Lietuva \\ Vilniaus pedagoginis universitetas², Vilnius, Lietuva \\ Lietuvos olimpinis sporto centras ${ }^{3}$, Vilnius. Lietuva \\ Lietuvos sporto medicinos centras, ${ }^{4}$,Vilnius, Lietuva \\ Lietuvos kūno kultūros akademija ${ }^{5}$, Kaunas, Lietuva
}

\section{SANTRAUKA}

Tyrimo pagrindimas ir hipotezė. Sportininkai, kultivuojantys sporto šakas pagal savo svorio kategorijas, dažnai prieš varžybas labai sumažina maisto raciono energinę vertę ir drastiškai mažina kūno masę. Hipotetiškai Lietuvos olimpinès pamainos graikų-romėnų imtynininkų maisto raciono maistinių ir biologiškai aktyvių medžiagų sudètis turi būti koreguojama individualiai.

Tikslas - ištirti ir ịvertinti trumpalaikio kūno masès mažinimo ypatumus ir jų daromą poveiki Lietuvos olimpinès pamainos graikų-romėnų imtynininkų $(\mathrm{n}=10)$ kūno masės komponentų (lieknosios kūno masės, riebalų masès, kūno skysčių, baltymų ir mineralinių medžiagų) rodikliams.

Metodai. Panaudojus faktinès mitybos apklausos metodą, iširta graikų-romėnų imtynininkų faktinè mityba prieš kūno masès mažinimą, jo metu ir po varžybų. Sportininkų kūno masès ir atskiru jos komponentu pokyčiams trumpalaikio kūno masès mažinimo metu nustatyti naudotas BIA tetra - poliarinis elektrodų metodas.

Rezultatai. Trumpalaikès graikų-romėnų imtynininkų sumažintos energinès vertės mitybos metu angliavandenių, baltymu ir riebalų kiekis vidutiniškai sudaro $18.2 \pm 10.6 \mathrm{kcal} \cdot \mathrm{kg}, 2.0 \pm 1.5 \mathrm{~g} \cdot \mathrm{kg}, 0.8 \pm 0.4 \mathrm{~g} \cdot \mathrm{kg}$ ir $0.8 \pm 0.4 \mathrm{~g} \cdot \mathrm{kg}$ kūno masės, o vitaminų $\mathrm{A}, \mathrm{B}_{1}, \mathrm{~B}_{2}, \mathrm{PP}, \mathrm{D}, \mathrm{E}, \mathrm{B}_{6}$, folio rūgšties ir mineralinių medžiagų kalio, kalcio, fosforo, magnio, geležies ir cinko kiekiai nesiekia rekomenduojamų. Atsigavimo laikotarpiu, po varžybų, nustatyta dvikovininku maisto raciono energinè vertè - angliavandenių ir skysčių kiekiai per maži.

Aptarimas ir išvados. Kūno masès mažinimo metu graikų-romėnų imtynininkų bendroji kūno masė, lieknoji kūno masè, viduląstelinių skysčiu kiekis, riebalų masė, mineralinių medžiagų ir organizmo baltymų kiekis sumažèjo atitinkamai $3.7 \pm 1.2 \mathrm{~kg}(\mathrm{p}<0.05), 1.5 \pm 1.3 \mathrm{~kg}(\mathrm{p} \leq 0.05), 0.8 \pm 0.5 \mathrm{~kg}(\mathrm{p}<0.05), 2.1 \pm 0.6 \mathrm{~kg}(\mathrm{p}<0.005), 0.2 \pm$ $0.1 \mathrm{~g}(\mathrm{p}<0.05)$ ir $0.2 \pm 0.1 \mathrm{~g}(\mathrm{p} \leq 0.05)$. Atsigavimo laikotarpiu, po varžybų, sportininkų organizmo lieknosios kūno masès $(p>0.05)$ ir bendrujų kūno skysčiu $(p>0.05)$ atsigavimo procesai per lèti.

Raktažodžiai: mityba, imtynininkų maisto racionas, kūno masès mažinimas.

Gauta $2011 \mathrm{~m}$. lapkričio $5 \mathrm{~d}$.

Received on November 5, 2011 